\title{
Effects of storage temperature on the physiological characteristics and vegetative propagation of desiccation-tolerant mosses
}

\section{Yuewei Guo and Yunge Zhao}

State Key Laboratory of Soil Erosion and Dry-land Farming on the Loess Plateau, Institute of Soil and Water Conservation, Northwest A \& F University, Yangling, 712100, Shaanxi, China

Correspondence: Yunge Zhao (zyunge@ms.iswc.ac.cn)

Received: 29 August 2017 - Discussion started: 11 September 2017

Revised: 24 December 2017 - Accepted: 4 January 2018 - Published: 8 February 2018

\begin{abstract}
Mosses, as major components of later successional biological soil crusts (biocrusts), play many critical roles in arid and semiarid ecosystems. Recently, some species of desiccation-tolerant mosses have been artificially cultured with the aim of accelerating the recovery of biocrusts. Revealing the factors that influence the vegetative propagation of mosses, which is an important reproductive mode of mosses in dry habitats, will benefit the restoration of moss crusts. In this study, three air-dried desiccationtolerant mosses (Barbula unguiculata, Didymodon vinealis, and Didymodon tectorum) were hermetically sealed and stored at five temperature levels $\left(0,4,17,25\right.$, and $\left.30^{\circ} \mathrm{C}\right)$ for 40 days. Then, the vegetative propagation and physiological characteristics of the three mosses were investigated to determine the influence of storage temperature on the vegetative propagation of desiccation-tolerant mosses and the mechanism. The results showed that the vegetative propagation of the three mosses varied with temperature. The most variation in vegetative propagation among storage temperatures was observed in $D$. tectorum, followed by the variation observed in B. unguiculata. In contrast, no significant difference in propagation among temperatures was found in D. vinealis. The regenerative capacity of the three mosses increased with increasing temperature from 0 to $17^{\circ} \mathrm{C}$, accompanied by a decrease in malondialdehyde (MDA) content, and decreased thereafter. As the temperature increased, the chlorophyll and soluble protein contents increased in B. unguiculata but decreased in D. vinealis and D. tectorum. As to storage, the MDA and soluble sugar contents increased after storage. The MDA content of the three mosses increased at each of the investigated temperatures by more than $50 \%$ from the initial values, and the soluble sugar content became
\end{abstract}

higher than before in the three mosses. The integrity of cells and cell membranes is likely the most important factor influencing the vegetative propagation of desiccation-tolerant mosses. A 40-day storage period caused cell injury. Our results suggest that storage temperature can enhance or suppress such injury and change the regenerative capacity of the three mosses. The data indicate that the suitable storage temperature is $4^{\circ} \mathrm{C}$ for $\mathrm{B}$. unguiculata and $17^{\circ} \mathrm{C}$ for both D. vinealis and D. tectorum.

\section{Introduction}

Biological soil crusts (biocrusts) are composed of microscopic (cyanobacteria, algae, fungi, and bacteria) and macroscopic (lichens, mosses) poikilohydric organisms (Belnap et al., 2016). Biocrusts are widely distributed in arid and semiarid ecosystems and play important roles in soil surface stabilization, soil fertility enhancement, and soil hydrology regulation (Belnap and Lange, 2003). As major components of later successional biocrusts, mosses exert much stronger ecological functions than cyanobacteria (Seppelt et al., 2016; Gao et al., 2017; Lan et al., 2012). Thus, some researchers suggest artificially culturing moss biocrusts on degraded soil surfaces to accelerate the recovery of degraded arid and semiarid ecosystems (Belnap and Eldridge, 2003; Zhao et al., 2016). Recently, some mosses have been investigated by culturing gametophytes (Jones and Rosentreter, 2006; Xiao et al., 2015). However, cultivation research on moss crusts remains tentative, potentially due to the lack of knowledge regarding the vegetative propagation of mosses. 
Vegetative propagation is an important reproduction mode of bryophytes (hornworts, liverworts, and mosses) in dry habitats, and gametophyte fragments may serve as the dominant inoculum in mosses (Mishler, 1988; Tian et al., 2005). To date, several moss cultivation experiments have been conducted in which gametophyte fragments are used to establish new colonies in the laboratory and field (Cleavitt, 2002; Jones and Rosentreter, 2006; Xiao et al., 2015). All of these experiments have demonstrated that artificial cultivation can accelerate the succession process of moss crusts. For example, Antoninka et al. (2016) found that the coverage and biomass of mosses on an artificially inoculated soil surface increased more rapidly than they did on uninoculated soil. Some researchers have suggested that inoculation material should be mass-produced by vegetative regeneration with rapid development (Jones and Rosentreter, 2006; Mishler, 1988) because of the need for moss biocrusts to inoculate large areas. The factors that influence the tissue cultivation of mosses have been investigated for many years (Duckett et al., 2004; Hoffman, 1966; Sabovljevic et al., 2003); however, the mechanism of moss regeneration remains unclear.

After mosses regenerate protonema and gametophytes suffer desiccation stress, desiccation tolerance (DT) has a critical influence on their survival and restoration abilities (Proctor et al., 2007). Adult gametophytes of some species can recover physiological activities and generate new shoots after being stored for more than 10 years in a desiccated state (Stark et al., 2017; Keever, 1957). Desiccation-tolerant mosses can suspend metabolism and maintain cell integrity during dry periods (Mansour and Hallet, 1981; Platt et al., 1994); then, within a few minutes to a few hours after being rehydrated, they can resume cellular activity and return to a normal, hydrated state (Platt et al., 1994; Pressel et al., 2006). However, the decline and disappearance of the regenerative capacity of Syntrichia ruralis showed that longterm desiccation can cause irreversible damage, despite viability differences among individuals (Stark et al., 2017). It remains unclear why the potential for vegetative propagation in mosses can be altered by storage and why recovery ability following drought-induced dormancy varies among moss species. The lack of knowledge in these areas has impeded the study of moss cultivation.

Investigations of DT in mosses have primarily focused on the mechanism and evolutionary history (Proctor et al., 2007; Oliver et al., 2000), with fewer investigations addressing DT in artificial cultivation. However, many studies suggest that DT research can help improve artificial cultivation methods. For example, the impact of desiccation stress on moss regeneration varies with drying time and storage temperature (Keever, 1957; Burch, 2003), and an understanding of these relationships may guide research on the regenerative mechanism of mosses upon desiccation and their asexual propagation. Furthermore, DT plays essential roles in moss regeneration in dry habitats, highlighting the potential value of investigating the relationships between the physiological char- acteristics of mosses and their vegetative propagation. Based on the above observations, it can be hypothesized that (1) dry storage impacts the vegetative propagation of desiccationtolerant mosses, (2) changes in vegetative propagation after storage involve the influences of storage on the physiological characteristics of mosses, and (3) the degree to which storage affects vegetative propagation and physiological characteristics is related to the storage temperature.

In this study, three desiccation-tolerant mosses, Barbula unguiculata, Didymodon vinealis, and Didymodon tectorum, which are the dominant mosses in biocrust communities in the Loess Plateau region, were stored at five temperatures $(0$, $4,17,25$, and $30^{\circ} \mathrm{C}$ ) for 40 days. Then, (1) the effect of storage temperature on the vegetative propagation of each moss and (2) the changes in physiological indices from before to after storage, including the contents of chlorophyll, soluble sugar, soluble protein, and malondialdehyde (MDA), were investigated to reveal the influences of storage temperature on the vegetative propagation of mosses and the mechanism.

\section{Materials and methods}

\subsection{Study site and moss species}

The study was conducted in Ansai Country, Shaanxi Provence, China $\left(36^{\circ} 51^{\prime} \mathrm{N}, 109^{\circ} 19^{\prime} \mathrm{E}\right)$, which is located in the central part of the Loess Plateau. The elevation of the sampling plot varies from 1068 to $1309 \mathrm{~m}$. The plot has a typical semiarid continental climate, with an average annual temperature of $8.8^{\circ} \mathrm{C}$, and its average temperature in January and July is -7.2 and $22.8^{\circ} \mathrm{C}$, respectively. The average annual precipitation is $500 \mathrm{~mm}$, with $60 \%$ or more of the precipitation falling between June and September (Zhang et al., 2011). For the month of November when the moss crusts were collected, the average monthly precipitation was $11.98 \mathrm{~mm}$, and the average monthly temperature was $9.88^{\circ} \mathrm{C}$ (high) to $-3.64{ }^{\circ} \mathrm{C}$ (low) (Chinese Central Meteorological Station, 2017). Cyanobacteria and mosses dominate the biocrust communities in this region, and the coverage of moss-dominated biocrusts can reach approximately $80 \%$ on north-facing slopes in the study region (Zhao et al., 2014).

The moss taxa used in the study were Barbula unguiculata, Didymodon vinealis, and Didymodon tectorum, which dominated the moss crusts in the plot. $B$. unguiculata dominated in woodland areas and was found in shaded areas and under vegetation coverage. $D$. vinealis was widely distributed in the study site among different water and light environments, and the species were collected from croplands that had been abandoned for more than 10 years. The dominant vegetation of the croplands was grasses; thus, most $D$. vinealis was exposed to sunlight in the winter. D. tectorum grew on side slopes and was occasionally collected from under the shade of vascular plants. 


\subsection{Experimental design}

Some of the three moss crusts were used to measure initial values of physiological indices (chlorophyll content, soluble sugar content, soluble protein content, and MDA content) and germination parameters (gametophyte germination, gametophyte increment, and gametophyte vigor index) immediately following their transport to the laboratory. The rest of the moss crusts were stored at one of five temperature levels, i.e., $0,4,17,25$, and $30^{\circ} \mathrm{C}$. Each temperature was controlled within $\pm 1{ }^{\circ} \mathrm{C}$ around the target. On the 41 st day of storage, the moss crusts were removed, and the physiological indices and germination parameters described above were measured.

\subsection{Moss crusts storage and mosses collection}

The crusts of three species of mosses were collected from many colonies and then air-dried in the shade for $24-48 \mathrm{~h}$; most of crust samples were dried in the field. Then, the samples were transported to the laboratory of the State Key Laboratory of Soil Erosion and Dry-land Farming on the Loess Plateau in Yangling, Shaanxi Province. Samples were stored in one of two refrigerators (at 0 or $4{ }^{\circ} \mathrm{C}$ ) or one of three growth chambers (at 17,25 , and $30^{\circ} \mathrm{C}$ ). Before storage, the moss crusts had been placed in resealable plastic bags to prevent changes in water content. The samples were stored in the dark under light-blocking fabric. The water content measurements of the moss gametophytes were all less than $10 \%$, and the equilibrating relative humidity during storage was $55 \%$. After the 40-day dry period, subsamples of desiccated gametophytes were collected to measure the physiological indices and germination parameters.

\subsection{Measurement of the physiological indices and germination parameters}

\subsubsection{Physiological indices}

Living mature gametophytes of B. unguiculata, D. vinealis, and $D$. tectorum were collected from the moss crusts. Shortly after being rehydrated and washed with deionized water, the gametophytes were measured for the contents of chlorophyll, soluble sugar, soluble protein, and MDA. Approximately $0.1 \mathrm{~g}$ fresh mass of gametophytes was used to measure the contents of soluble sugar, soluble protein, and MDA in each replicate, whereas the measurements of chlorophyll content used approximately $0.05 \mathrm{~g}$ fresh mass per replicate. The four indicators were measured by using the following protocols with three replications.

The chlorophyll was extracted by $95 \%(v / v)$ ethanol, and the solution was boiled at $85^{\circ} \mathrm{C}$ for $5 \mathrm{~min}$. After being centrifuged at $4000 \mathrm{rpm}$ for $10 \mathrm{~min}$, the chlorophyll in the supernatant was measured at absorbances of 665 and $649 \mathrm{~nm}$ with a spectrophotometer (UV-2300; Techcomp, Shanghai, China; Wellburn and Lichtenthaler, 1984).
After the soluble protein was extracted in ice-cold $50 \mathrm{mmol} \mathrm{L}^{-1}$ phosphate buffer ( $\mathrm{pH} 7.8$ ), the suspension was centrifuged at $8000 \mathrm{rpm}$ for $30 \mathrm{~min}$ at $4{ }^{\circ} \mathrm{C}$, and the supernatant was collected. The soluble protein was stained with Coomassie brilliant blue G-250, and the absorbance was read at $595 \mathrm{~nm}$ (Bradford, 1976).

MDA and soluble protein were extracted and centrifuged. Then, the supernatant was homogenized with $0.6 \%(\mathrm{~W} / \mathrm{V})$ thiobarbituric acid dissolved by $1 \mathrm{molL}^{-1} \mathrm{NaOH}$ and $10 \%$ $(W / V)$ trichloroacetic acid. The mixed solution was heated at $100{ }^{\circ} \mathrm{C}$ for $20 \mathrm{~min}$, and then the absorbance was read at 450, 523, and $600 \mathrm{~nm}$ (Hodges et al., 1999). The Techcomp UV-2300 spectrophotometer was used to measure the absorbance of the MDA and soluble protein.

Soluble sugar was extracted by distilled water at $100^{\circ} \mathrm{C}$ for $30 \mathrm{~min}$. After being filtered and diluted, the extract was added to an anthrone-sulfuric acid solution. The mixed solution was used to measure the absorbance at $620 \mathrm{~nm}$ with a spectrophotometer (UV-1601; Shimadzu, Kyoto, Japan; Morris, 1948).

The fresh weight of gametophytes was measured shortly after rehydration, and dry weight was measured after oven drying to a constant weight at $70^{\circ} \mathrm{C}$ (Schonfeld et al., 1988). The fresh and dry weights were used to calculate the four physiological indices on a dry basis.

\subsubsection{Germination parameters}

At the same time as the physiological indices was measured, some gametophytes of each of the three moss species were collected to measure the germination parameters. The loessial soil (uniform soil texture of Calciustepts) collected from the study region was used to culture the mosses. The soil was sieved through a $0.25 \mathrm{~mm}$ mesh and placed in each pore of a six-well plate; each pore had a diameter of $35 \mathrm{~mm}$ and a depth of $12 \mathrm{~mm}$. Then, the soil water content was adjusted to $23 \%(W / W)$ (the field water-holding capacity of the soil) by adding deionized water, and the surface was flattened before inoculation. Five inocula representing the top $2 \mathrm{~mm}$ of living mature gametophytes of the mosses were cut, rehydrated, washed, and placed in each well. Thirty inocula were placed in each six-well plate as one replication. Three sixwell plates were established for each moss species. In total, 90 experimental inoculations were established for the measurement of germination parameters before and after storage at each of the five temperature levels for each moss species. Meanwhile, three six-well plates without inoculated mosses were set up as experimental controls for the effect of other propagules, such as spores, in the experimental soil. The six-well plates were wrapped tightly with transparent plastic film to retain the soil moisture. Next, they were placed into a growth chamber (AGC-D003N; Qiushi, Hangzhou, China) to incubate. The parameters of the growth chamber were set to a $12 \mathrm{~h}$ photoperiod (4500-5500 Lux), a constant temperature of $17^{\circ} \mathrm{C}\left( \pm 1^{\circ} \mathrm{C}\right)$, and a relative humidity of $60-70 \%$. 
During the incubation period, deionized water was supplied to maintain the soil moisture at $23 \%$. The new gametophytes were counted every 5 days beginning on the day they were found. Five observations were made over the subsequent 25 days. This paper reports the results of cultivation at the fifth observation. No new gametophytes were found in the blank six-well plates during the entire incubation period. It was difficult to distinguish protonemal germination between the underside of original inocula and the soil substrate; therefore, protonemal growth was not quantified.

By analogy with seed germination, the vegetative propagation of moss gametophytes was described by three germination parameters: gametophyte germination, gametophyte increment and the gametophyte vigor index. In this paper, gametophyte germination is defined as the percent of moss inocula that germinated. Gametophyte increment is the average number of new gametophytes per six-well plate. The gametophyte vigor index is analogous to the seed vigor index, which is calculated by multiplying the seed germination percentage by the length of the hypocotyl (Abdul-baki and Anderson, 1973). Here, the seed germination percentage and the length of hypocotyl were replaced by the gametophyte germination and gametophyte increment, respectively, and used to calculate the gametophyte vigor index. Thus, the germination parameters were calculated by using Eqs. (1)-(3).

gametophyte germination

$$
=\frac{\text { number of germinated inocula }}{\text { number of total inocula }} \times 100 \%
$$

gametophyte increment $=\frac{\text { number of new gametophyte }}{\text { number of total inocula }}$

gametophyte vigor index $=$ gametophyte germination

$$
\times \text { gametophyte increment }
$$

According to Eqs. (1)-(3), the gametophyte vigor index summarizes the vegetative propagation of the mosses.

\subsection{Statistical analyses}

The differences in physiological indices and germination parameters among treatments and mosses were tested using one-way analysis of variance (ANOVA) with Fisher's least significant difference post hoc test (LSD) at $P<0.05$. The relationships between the physiological indices and germination parameters of the three moss species were quantified by calculating Pearson correlation coefficients. These statistical analyses were completed using SPSS 22.0.

The effects of physiological characteristics on vegetative propagation were analyzed by a gray incidence analysis in Microsoft Excel 2010 (Deng, 1982; Lin et al., 2009). The gray incidence degree between each of the reference sequences (physiological indices) and the compared sequence (gametophyte vigor index) was calculated by using Eqs. (4)-
(6):

$$
\begin{aligned}
& \Delta_{i}(k)=\left|y(k)-x_{i}(k)\right|, k=1,2, \ldots \ldots, n ; i=1,2,3,4 \\
& \xi_{i}\left(X_{i}, Y\right)=\frac{\min _{i} \min _{k} \Delta_{i}(k)+\rho \max _{i} \max _{k} \Delta_{i}(k)}{\Delta_{i}(k)+\rho \max _{i} \max _{k} \Delta_{i}(k)}, \\
& k=1,2, \ldots \ldots, n ; \quad i=1,2,3,4, \\
& r_{i}=\frac{1}{n} \sum_{k=1}^{n} \xi_{i}(k), \quad k=1,2, \ldots \ldots, n ; \quad i=1,2,3,4 .
\end{aligned}
$$

where $\Delta_{i}(k)$ and $\xi_{i}\left(X_{i}, Y\right)$ are the absolute difference and the gray relational coefficient, respectively, between $X_{i}$ (physiological index $i$ ) and $Y$ (gametophyte vigor index) at point $k$. The gray relational coefficient $\left(r_{i}\right)$ is between the $i$ th physiological index and its gametophyte vigor index when the distinguishing coefficient $(\rho)$ is 0.5 .

The gray incidence degree is the sum of the gray relational coefficients.

\section{Results}

\subsection{The initial measurement values of the mosses}

The three moss species began to germinate new gametophytes from the original inocula at different times, whereas no gametophyte germinated in the control groups as of the final (fifth) observation. B. unguiculata germinated on the 11th day of inoculation, and the entire length of its cultivation period was 35 days. $D$. vinealis and $D$. tectorum each germinated on the sixth day, with a 30-day cultivation period. The initial values of the physiological indices and germination parameters of the three mosses are shown in Table 1 . It can be seen that the four physiological indices and gametophyte germination of $D$. vinealis were significantly higher than those of the other two species. The largest values of gametophyte increment and gametophyte vigor index were found in D. tectorum, and the lowest germination parameter values were found in B. unguiculata. However, no significant differences in the contents of chlorophyll, soluble protein, and MDA between $D$. tectorum and B. unguiculata were found.

\subsection{Effect of storage temperature on the vegetative propagation of mosses}

The germination times of each of the three mosses after storage at each temperature did not differ significantly from the initial values, whereas controls still had no gametophyte. At the fifth observation, the gametophyte germination of each of the three species had changed from the initial value by no more than $20 \%$ (Fig. 1a; Table 1). The highest gametophyte germination of B. unguiculata was $94.44 \%$ at $17^{\circ} \mathrm{C}$. No significant difference was found between the maximum value and minimum value $\left(75.56 \%\right.$ at $\left.0{ }^{\circ} \mathrm{C}\right)$. In $D$. vinealis, gametophyte germination did not significantly differ among the storage temperatures and ranged from $95.56 \%\left(0{ }^{\circ} \mathrm{C}\right)$ to 

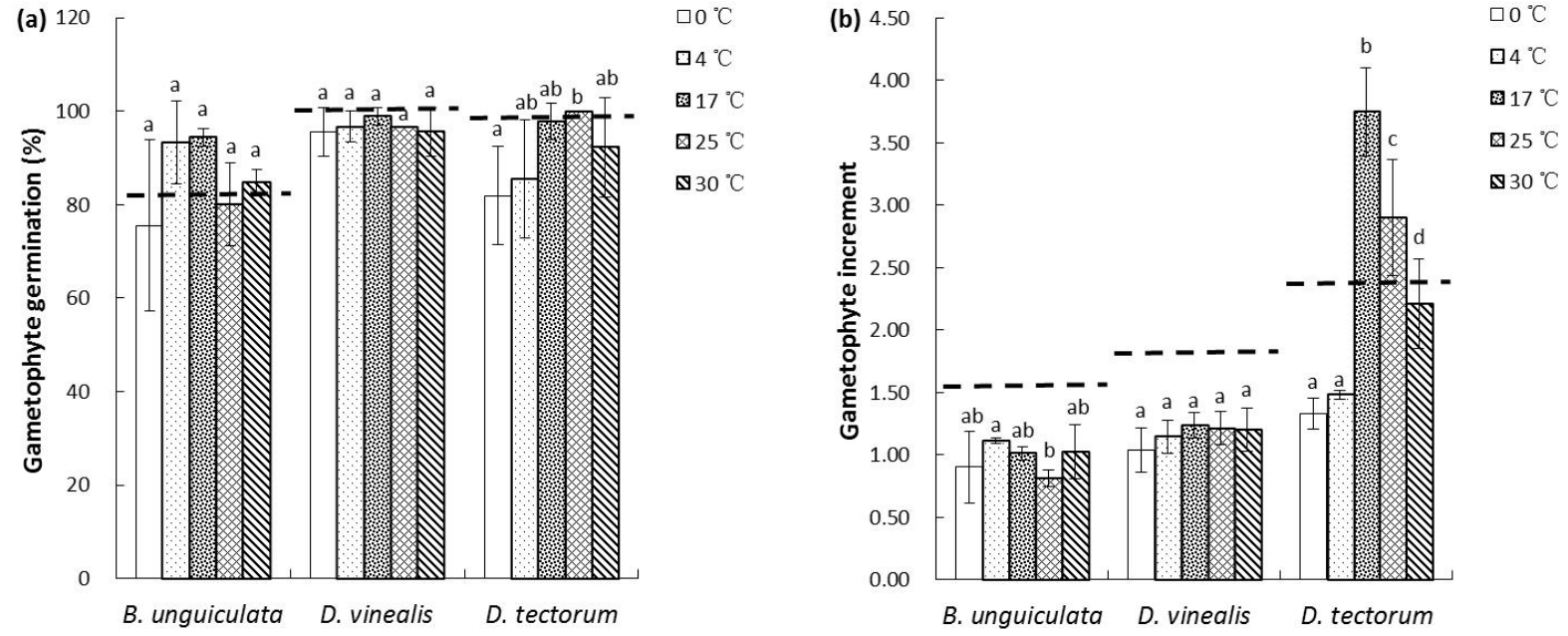

Figure 1. Data (average $\pm 1 \mathrm{SE}$ ) for the three moss species on (a) gametophyte germination and (b) gametophyte increment after the 40-day storage period at each of the five temperatures. Different letters indicate significant differences $(P<0.05)$ among the five temperatures within the same species. Dotted lines represent the approximate values of the two germination parameters before storage for each species (the true values are shown in Table 1).

Table 1. Initial values of physiological indices and germination parameters in the three mosses.

\begin{tabular}{lrrr}
\hline Index & B. unguiculata & D. vinealis & D. tectorum \\
\hline Chlorophyll content $\left(\mathrm{mg} \mathrm{g}^{-1}\right)$ & $1.53 \pm 0.13 \mathrm{a}$ & $3.33 \pm 0.18 \mathrm{~b}$ & $2.19 \pm 0.44 \mathrm{a}$ \\
Soluble sugar content $\left(\mathrm{mg} \mathrm{g}^{-1}\right)$ & $30.02 \pm 3.67 \mathrm{a}$ & $44.13 \pm 3.41 \mathrm{~b}$ & $14.19 \pm 1.77 \mathrm{c}$ \\
Soluble protein content $\left(\mathrm{mgg}^{-1}\right)$ & $6.28 \pm 1.40 \mathrm{a}$ & $12.24 \pm 0.26 \mathrm{~b}$ & $7.92 \pm 0.46 \mathrm{a}$ \\
MDA content $\left.(\mu \mathrm{molg})^{-1}\right)$ & $24.02 \pm 0.47 \mathrm{a}$ & $35.07 \pm 3.12 \mathrm{~b}$ & $23.68 \pm 0.50 \mathrm{a}$ \\
Gametophyte germination $(\%)$ & $82.93 \pm 10.00 \mathrm{a}$ & $100.00 \pm 0.00 \mathrm{a}$ & $98.33 \pm 2.36 \mathrm{a}$ \\
Gametophyte increment & $1.54 \pm 0.18 \mathrm{a}$ & $1.82 \pm 0.40 \mathrm{ab}$ & $2.37 \pm 0.05 \mathrm{~b}$ \\
Gametophyte vigor index & $1.28 \pm 0.15 \mathrm{a}$ & $1.82 \pm 0.40 \mathrm{ab}$ & $2.33 \pm 0.05 \mathrm{~b}$ \\
\hline
\end{tabular}

Data are average $\pm 1 \mathrm{SE}$, and different letters indicate significant differences $(P<0.05)$ among the three species.

$98.89 \%\left(17^{\circ} \mathrm{C}\right)$. The only significant difference in gametophyte germination was observed in $D$. tectorum and was between 81.92 and $100 \%$ after storage at 0 and $25^{\circ} \mathrm{C}$, respectively.

The changes in gametophyte increment were all more than $20 \%$ after storage except in D. tectorum at $30^{\circ} \mathrm{C}$, for which a slight decrease of $6.57 \%$ was observed (Fig. 1b; Table 1). After storage, the largest gametophyte increment of $B$. unguiculata was 1.11 at $4{ }^{\circ} \mathrm{C}$, whereas the smallest gametophyte increment was 0.81 at $25^{\circ} \mathrm{C}$. Except for a significant difference between 4 and $25^{\circ} \mathrm{C}$, no significant difference in gametophyte increment was found among the storage temperatures in B. unguiculata. Similarly, no significant difference in the gametophyte increment of $D$. vinealis was observed among the storage temperatures. The maximum and minimum gametophyte increments after storage were 1.03 and 1.23 at 0 and $17^{\circ} \mathrm{C}$, respectively, for $D$. vinealis. Larger differences in gametophyte increment among the storage temperatures were observed in $D$. tectorum except for the difference in gametophyte increment between 0 and $4{ }^{\circ} \mathrm{C}$. The maximum gametophyte increment of $D$. tectorum was 3.74 at $17^{\circ} \mathrm{C}$ after storage, and the minimum value was 1.32 at $0{ }^{\circ} \mathrm{C}$.

The gametophyte vigor index of the three moss species showed significant changes over the 40-day storage period (Table 2). The largest changes in gametophyte vigor index after storage were observed in D. tectorum, with the index ranging from a $53.36 \%$ decrease $\left(0^{\circ} \mathrm{C}\right)$ from the initial value to a $57.32 \%$ increase $\left(17^{\circ} \mathrm{C}\right)$. No significant difference in the gametophyte vigor index among the five temperatures was observed in $D$. vinealis. However, the index values were all significantly lower than the initial value (before storage), representing decreases of $32.86 \%\left(17^{\circ} \mathrm{C}\right)$ to $45.65 \%\left(0^{\circ} \mathrm{C}\right)$. After storage, the gametophyte vigor index values of $B$. unguiculata decreased the least by $18.81 \%$ at $4{ }^{\circ} \mathrm{C}$ and the most by $49.20 \%$ at $25^{\circ} \mathrm{C}$, representing changes between those of D. vinealis and D. tectorum.

After the 40-day storage at the five temperatures, the highest gametophyte germination percentages of $B$. unguiculata and $D$. vinealis were at $17^{\circ} \mathrm{C}$, whereas the highest percent- 
Table 2. Gametophyte vigor index of the three mosses under treatments.

\begin{tabular}{lrrr}
\hline Treatment & B. unguiculata & D. vinealis & D. tectorum \\
\hline Initial value & $1.28 \pm 0.15 \mathrm{a}$ & $1.82 \pm 0.40 \mathrm{a}$ & $2.33 \pm 0.05 \mathrm{a}$ \\
$0^{\circ} \mathrm{C}$ & $0.68 \pm 0.22 \mathrm{~b}$ & $0.99 \pm 0.17 \mathrm{~b}$ & $1.09 \pm 0.10 \mathrm{~b}$ \\
$4{ }^{\circ} \mathrm{C}$ & $1.04 \pm 0.02 \mathrm{ac}$ & $1.11 \pm 0.13 \mathrm{~b}$ & $1.26 \pm 0.03 \mathrm{~b}$ \\
$17^{\circ} \mathrm{C}$ & $0.95 \pm 0.05 \mathrm{c}$ & $1.22 \pm 0.10 \mathrm{~b}$ & $3.66 \pm 0.35 \mathrm{c}$ \\
$25^{\circ} \mathrm{C}$ & $0.65 \pm 0.06 \mathrm{~b}$ & $1.17 \pm 0.13 \mathrm{~b}$ & $2.90 \pm 0.46 \mathrm{a}$ \\
$30^{\circ} \mathrm{C}$ & $0.86 \pm 0.18 \mathrm{bc}$ & $1.15 \pm 0.17 \mathrm{~b}$ & $2.04 \pm 0.33 \mathrm{a}$ \\
\hline
\end{tabular}

Data are average $\pm 1 \mathrm{SE}$, and different letters indicate significant differences $(P<0.05)$ among treatments within the same species.

age in D. tectorum was at $25^{\circ} \mathrm{C}$. The highest gametophyte increment of $B$. unguiculata was at $4^{\circ} \mathrm{C}$. The highest gametophyte increment values in $D$. vinealis and $D$. tectorum were both at $17^{\circ} \mathrm{C}$, as observed for the gametophyte vigor index values of these two species.

\subsection{Effects of storage temperature on the physiological indices of mosses}

As shown in Table 1 and Fig. 2a, the chlorophyll content of $B$. unguiculata increased after storage at four of the five temperatures, i.e., all but $0^{\circ} \mathrm{C}$. The chlorophyll content of $B$. unguiculata showed an increasing trend with increasing storage temperature, with the maximum increase of $73.08 \%$ observed at $30^{\circ} \mathrm{C}$. The smallest change in chlorophyll content was observed in $D$. vinealis, which showed a maximum decrease of $17.89 \%$ at $4{ }^{\circ} \mathrm{C}$ and a minimum decrease of $2.39 \%$ at $17^{\circ} \mathrm{C}$. The chlorophyll content of $D$. tectorum after storage was decreased by $31.51 \%$ at $17^{\circ} \mathrm{C}$ and increased by $18.50 \%$ at $25^{\circ} \mathrm{C}$, yielding the highest and lowest content values, respectively.

A similar increasing trend with temperature was found for soluble sugar content (Fig. 2b). The soluble sugar content was consistently higher after storage than before except in $B$. unguiculata, in which sugar content was decreased by 56.52 and $40.47 \%$ at 0 and $4{ }^{\circ} \mathrm{C}$, respectively (Fig. 2b; Table 1). The soluble sugar content of $D$. vinealis showed less variation than the other species. No significant difference was found between the minimum and maximum increases, which were $9.92 \%$ at $0{ }^{\circ} \mathrm{C}$ and $23.14 \%$ at $25^{\circ} \mathrm{C}$, respectively. The greatest changes in soluble sugar content, with greater than $65 \%$ increases at all storage temperatures, occurred in D. tectorum.

MDA content showed greater variation than sugar content, increasing by more than $50 \%$ in all stored gametophytes (Fig. 2d; Table 1). The MDA content of both B. unguiculata and $D$. tectorum decreased as the temperature increased from 0 to $17^{\circ} \mathrm{C}$; the minimum value of MDA content (at $17^{\circ} \mathrm{C}$ ) was 1.70 times and 2.06 times the initial value, respectively. However, the MDA content of D. vinealis was 1.54 to
2.98 times the initial value after storage and continuously decreased with increasing temperature.

Some temperatures caused the soluble protein content to change significantly (Fig. 2c; Table 1). The soluble protein content of B. unguiculata increased abruptly from a $31.79 \%$ decrease from the initial value to a $40.06 \%$ increase with increasing temperature. In contrast, soluble protein showed the opposite trend in $D$. vinealis and $D$. tectorum. Both species presented a maximum increase at $0{ }^{\circ} \mathrm{C}$, which was $16.64 \%$ in $D$. vinealis and $23.65 \%$ in D. tectorum. The lowest soluble protein content of $D$. vinealis and D. tectorum represented a decrease of $16.00 \%$ at $25^{\circ} \mathrm{C}$ and a decrease of $21.38 \%$ at $30^{\circ} \mathrm{C}$, respectively.

Our results indicated that the sharpest changes in chlorophyll content and soluble protein content with increasing temperature were observed in B. unguiculata; furthermore, soluble sugar content and MDA content changed more rapidly with increasing temperature in this species than in D. vinealis and D. tectorum (Fig. 2a-d; Table 1). D. vinealis showed slower changes in chlorophyll, soluble sugar, and soluble protein contents with increasing temperature than the other two species. MDA content, however, varied widely with temperature. The largest increases in soluble sugar content and MDA content after 40 days of storage were observed in D. tectorum. In all three moss species, the greatest changes were observed in MDA content, followed by soluble sugar content (Fig. 2b and d; Table 1).

\subsection{Relationships between physiological characteristics and the vegetative propagation of mosses}

After analyzing the correlations between the physiological indices and germination parameters of the desiccationtolerant mosses, a significant correlation $(P<0.01)$ was found between each physiological index except for chlorophyll content and MDA content (Table 3). Gametophyte germination was significantly correlated $(P<0.05)$ with soluble protein content and highly significantly correlated $(P<0.01)$ with both chlorophyll content and soluble sugar content. MDA content was significantly negatively correlated $(P<0.05)$ with both gametophyte increment and gametophyte vigor index.

At a distinguishing coefficient of 0.5 , the gray incidence degrees between the physiological indices (X1: chlorophyll content; X2: soluble sugar content; X3: soluble protein content; X4: MDA content) and the gametophyte vigor index in the three moss species were (1) $\mathrm{X} 4>\mathrm{X} 1>\mathrm{X} 2=\mathrm{X} 3$ in B. unguiculata, (2) $\mathrm{X} 3>\mathrm{X} 4>\mathrm{X} 2>\mathrm{X} 1$ in D. vinealis, and (3) $\mathrm{X} 4>\mathrm{X} 3>\mathrm{X} 1>\mathrm{X} 2$ in D. tectorum (Table 4). 

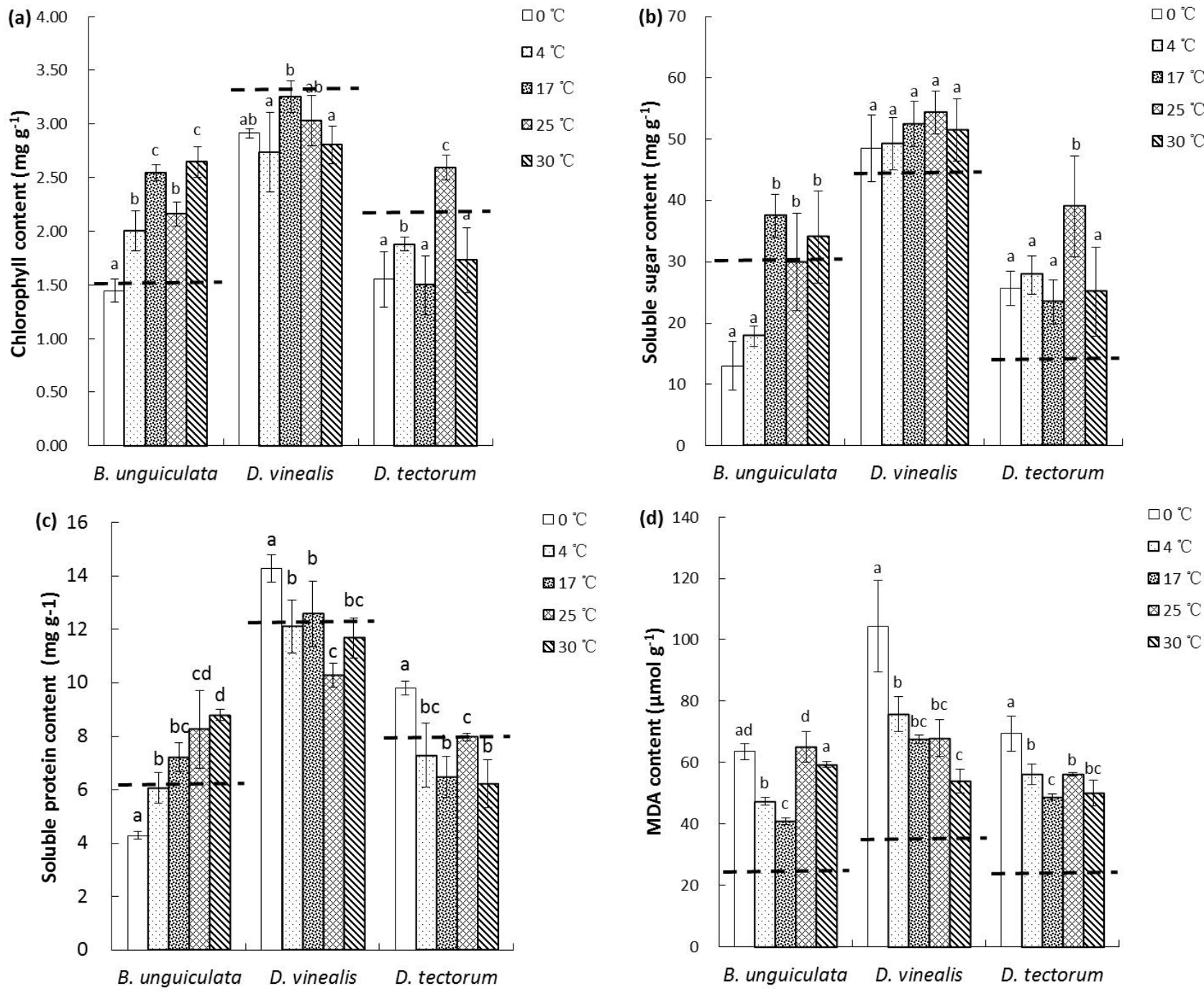

Figure 2. (a-d) Data (average $\pm 1 \mathrm{SE}$ ) for the three moss species on (a) chlorophyll content, (b) soluble sugar content, (c) soluble protein content, and (d) MDA content after the 40-day storage period at each of the five temperatures. Different letters indicate significant differences $(P<0.05)$ among the five temperatures within the same species. Dotted lines represent the approximate values of the two germination parameters before storage for each species (the true values are shown in Table 1).

Table 3. Correlation coefficients between physiological indices and germination parameters across all mosses and treatments.

\begin{tabular}{lrrrrrr}
\hline Variables & Chlorophyll & Sugar & Protein & MDA & Germination & Increment \\
\hline Sugar & $0.762^{* *}$ & & & & & \\
Protein & $0.747^{* *}$ & $0.781^{* *}$ & & & & \\
MDA & 0.220 & $0.402^{* *}$ & $0.510^{* *}$ & & & \\
Germination & $0.473^{* *}$ & $0.414^{* *}$ & $0.313^{*}$ & -0.022 & & \\
Increment & -0.239 & -0.187 & -0.249 & $-0.344^{*}$ & $0.388^{* *}$ & \\
Vigor index & -0.158 & -0.122 & -0.191 & $-0.328^{*}$ & $0.441^{* *}$ & $0.995^{* *}$ \\
\hline
\end{tabular}

Chlorophyll: chlorophyll content; sugar: soluble sugar content; protein: soluble protein content; MDA: MDA content; germination: gametophyte germination; increment: gametophyte increment; vigor index: gametophyte vigor index. The * symbol indicates a significant correlation at $P<0.05$; ** indicates a significant correlation at $P<0.01$. 
Table 4. Gray incidence degree between physiological indices and the gametophyte vigor index across all treatments.

\begin{tabular}{lccc}
\hline Reference sequences & B. unguiculata & D. vinealis & D. tectorum \\
\hline Chlorophyll content (X1) & $0.60 \pm 0.20$ & $0.55 \pm 0.27$ & $0.66 \pm 0.21$ \\
Soluble sugar content (X2) & $0.57 \pm 0.20$ & $0.62 \pm 0.23$ & $0.62 \pm 0.17$ \\
Soluble protein content (X3) & $0.57 \pm 0.22$ & $0.74 \pm 0.28$ & $0.70 \pm 0.25$ \\
MDA content (X4) & $0.77 \pm 0.20$ & $0.73 \pm 0.22$ & $0.76 \pm 0.27$ \\
\hline
\end{tabular}

\section{Discussion}

\subsection{Effects of storage temperature on the vegetative propagation of mosses}

For more than a century, researchers have studied many aspects of mosses, such as inocula, pretreatment (e.g., storage and sterilization), culture methods, and culture conditions (Duckett et al., 2004; Hoffman, 1966). Some of these studies have implied that the physiological characteristics of moss gametophytes are closely related to the success of artificial cultivation; for example, pretreatment with sucrose and/or abscisic acid can improve the viability of mosses by increasing DT (Burch and Wilkinson, 2002). In line with previous studies, this study found that gametophyte regeneration within the same species after desiccation varied among different temperatures (Fig. 1a and b; Table 2), which is likely related to species-specific DT. The regenerative capacity of mosses can be summarily described by the gametophyte vigor index on the basis of Eqs. (1)-(3) and Table 3. The gametophyte vigor index most sensitive to storage temperature was that of $D$. tectorum, whereas that of $D$. vinealis varied little with storage temperature, with no significant differences among temperatures (Table 2). Thus, the effect of storage temperature on regenerative capacity was strongest in D. tectorum and weakest in D. vinealis.

The 40-day storage period adversely affected regeneration in most gametophytes (Fig. 1a and b; Table 1); however, some gametophytes of $D$. tectorum stored at 17 and $25^{\circ} \mathrm{C}$ produced more new shoots than before. It is not clear whether this enhanced regeneration was associated with the low-temperature tolerance of $D$. tectorum. D. tectorum possibly suffered low-temperature stress in early winter. Furthermore, higher temperatures (e.g., $30^{\circ} \mathrm{C}$ ) injured the gametophytes of $D$. tectorum, as did the lower temperatures of 0 and $4{ }^{\circ} \mathrm{C}$. These findings suggest that extreme temperatures are unsuitable for storing this moss species. Further studies are warranted on the impact of the storage environment on desiccation-tolerant mosses. For example, Burch (2003) found that the survival and regeneration of dehydrated protonemata were reduced after cryopreservation due to damage caused by intracellular ice crystals. The desiccation time can also affect the restorability of vegetative propagation in desiccation-tolerant mosses and their physiological characteristics (Keever, 1957; Proctor, 2001). Environmental changes or variation in the dormancy period of cells might influence the restoration results after rehydration.

\subsection{Effects of storage temperature on the physiological characteristics of mosses}

MDA, an important product of membrane lipid peroxidation, increased in all mosses over the storage period. This finding indicated that the 40-day storage period caused cell damage (Fig. 2d; Table 1). Accordingly, the soluble sugar content increased to protect the membranes and proteins in the dried gametophytes (Fig. 2b; Table 1). Sugars are the main substance used to stabilize protein structures in desiccationtolerant cells (Hoekstra et al., 2001). However, the soluble sugar content of B. unguiculata stored at 0 and $4{ }^{\circ} \mathrm{C}$ was decreased relative to the initial value. This result might have been due to the low temperatures preventing the conversion from starch to soluble sugar (Pressel et al., 2006). When mosses suffered oxidative damage, the increases in chlorophyll content and soluble protein content in some gametophytes were related to the recovery ability of desiccationtolerant cells (Fig. 2a and c; Table 1). In previous studies, the chlorophyll content of mosses increased during desiccation, and their photosynthetic capacity recovered rapidly after rewetting (Alpert, 1988; Csintalan et al., 1999). Similarly, protein synthesis recovered after rehydration (Oliver, 1991) since cellular recovery is an important part of DT (Proctor et al., 2007).

The recovery of photosynthesis and protein synthesis in B. unguiculata was facilitated by higher temperatures (not more than $30^{\circ} \mathrm{C}$; Fig. $2 \mathrm{a}$ and c). This finding is inconsistent with the pattern in other mosses, in which viability tends to be lower at increased temperatures (Hearnshaw and Proctor, 1982). However, the increasing trend of MDA content from 17 to $30^{\circ} \mathrm{C}$ suggests that more extensive membrane damage may be caused by storage temperatures above $30^{\circ} \mathrm{C}$ (Fig. 2d). The adverse effects of the higher temperatures in D. vinealis and D. tectorum were clearly reflected by the slower recovery of photosynthesis and protein synthesis (Fig. 2a and c). The changes in the MDA content in $D$. vinealis suggested more rapid repair of cell membrane with increasing temperature; however, the species possibly had stronger tolerance under the protection of abundant sugars when the recovery of photosynthesis and protein synthesis was slower (Fig. 2a-d). 
The responses of the physiological characteristics of the three species to temperature reflected species variation in restoration ability over a short rehydration time. Because the rewetting periods were longer than 30 days in the cultivation, the vegetative propagation results can be considered as reflecting the long-term recovery of mosses. Thus, the longterm effect of cell recovery during short-term rehydration can be explained by the relationships between the physiological characteristics and vegetative propagation of desiccationtolerant mosses.

\subsection{Relationships between physiological characteristics and the vegetative propagation of mosses}

Before storage, the four physiological indices of gametophytes showed significant differences between $D$. vinealis and D. tectorum. However, no significant differences between the two species were observed in regard to the three germination parameters (Table 1). Mosses of similar fertility showed significant differences in physiological characteristics. Species differences in DT led to larger differences in vegetative propagation among species than before, as evidenced by the values of the gametophyte vigor indices within the same treatment (Tables 1 and 2). Therefore, the recovery ability of dried mosses with respect to development and regeneration might be more informative for screening suitable inocula than using fresh mosses in dry habitats. Many studies have indicated that desiccation-tolerant mosses can recover from drying once they are rehydrated (Csintalan et al., 1999; Pressel et al., 2006). However, long periods of desiccation would impede the reuse of moss specimens and the restoration of dried biocrusts. This study showed that cells were subjected to oxidative damage after the 40-day desiccation period (Fig. 2d; Table 1). Over this period, the regenerative capacity of the three species declined (Table 2), which suggested that membrane integrity and/or other factors affected the vegetative propagation of the desiccation-tolerant mosses.

Based on the correlation coefficients among the physiological indices and germination parameters of desiccationtolerant mosses (Table 3), gametophyte germination was significantly and positively correlated with chlorophyll content, soluble sugar content, and soluble protein content. In addition, gametophyte increment and gametophyte vigor index were significantly and negatively correlated with MDA content. These findings are in accordance with the observations that metabolic repair is favorable to the germination of new gametophytes and that long-term recovery is more dependent on cell integrity than metabolic repair. Therefore, to quantitatively compare the effects of the four physiological indices on vegetative propagation, the gray incidence degree between the physiological indices and the gametophyte vigor index for each of the three moss species was calculated by using Eqs. (4)-(6). As shown in Table 4, the effect of MDA content on the gametophyte vigor index was the strongest in B. unguiculata and D. tectorum, and the incidence degree of MDA (0.73) in D. vinealis was similar to the maximum (0.74). In all three mosses, MDA content increased as storage temperature decreased from 17 to $0^{\circ} \mathrm{C}$. Smaller gametophyte vigor index values were observed for $D$. vinealis and D. tectorum at 0 and $4{ }^{\circ} \mathrm{C}$ than at 25 and $30^{\circ} \mathrm{C}$ (Fig. $2 \mathrm{~d}$; Table 2). This result indicated that the greater membrane damage incurred at low temperatures caused the decline in regenerative capacity. In addition, the higher gametophyte vigor index values of D. tectorum at 17 and $25^{\circ} \mathrm{C}$ than before storage were possibly related to the reduced formation of intracellular ice crystals at these temperatures during the storage period (Burch, 2003), which facilitated more rapid recovery upon rehydration (Table 2). However, the number of negative effects on physiological characteristics increased with increasing temperature (Fig. 2a-c). The high temperatures were unfavorable to the recovery of the mosses (Hearnshaw and Proctor, 1982). When cells suffered damage under desiccation and temperature stress, the protection provided by additional sugars was important for maintaining cell integrity in the dry state (Fig. 2d; Table 1). D. vinealis showed no significant difference in regenerative capacity among temperatures, potentially because the level of cellular protection was equivalent among the different temperatures.

Researchers have summarized the recovery mechanisms of mosses upon rehydration, such as the rapid recovery of photosynthesis, respiration, and protein synthesis within minutes to hours (Proctor et al., 2007). However, recovery of the carbon balance, cell cycle, and the cytoskeleton require more than 24 h (Alpert and Oechel, 1985; Mansour and Hallet, 1981; Pressel et al., 2006). Based on these results, it has been speculated that cell integrity is more difficult to recover than physiological reactions and that cell integrity greatly limits the recovery and regenerative capacity of desiccationtolerant mosses. Over long-term desiccation, the cumulative damage affects cell function and integrity (Proctor, 2001); different temperatures might enhance or suppress such cell damage. Thus, the effects of temperature on the ecology of DT in bryophytes warrant investigation, especially during the dry season in semiarid and arid areas. The greater sensitivity of $D$. tectorum observed here might provide insight into why this species is not a widely distributed species, such as $D$. vinealis, in the study region. Furthermore, the ecological niche requirements of different mosses in both dry and wet periods will influence the choice of moss inocula for artificial cultivation and biocrust restoration. Field studies are needed to better understand the ecological requirements of dried mosses. Furthermore, a precise description of microclimates and the application of quantitative methods would be helpful. 


\section{Conclusions}

The conducted experiment explored the effect of storage temperature on the vegetative propagation of desiccation-tolerant mosses and influencing factors. The results indicated that the decline in regenerative capacity in mosses observed following storage was related to cell damage caused by dehydration during storage. The storage temperature during dehydration influenced the vegetative propagation of mosses through changes in moss cell activity. Further analysis showed that the factor with the strongest effect on vegetative propagation was membrane damage. During storage, soluble sugars increased to protect the cells, highlighting the important role of cell integrity in influencing the physiological characteristics and vegetative propagation of desiccation-tolerant mosses. In this study, the optimal storage temperature of $D$. vinealis and D. tectorum was $17^{\circ} \mathrm{C}$, whereas the optimal temperature for B. unguiculata was $4{ }^{\circ} \mathrm{C}$. Different responses to temperature among the three moss species were associated with species differences in DT. These findings can potentially guide future research on suitable storage methods for inoculation material to improve the artificial cultivation of moss biocrusts.

In general, the properties of inoculation material are key factors affecting the development and recovery of moss biocrusts, such as species, physiological features, and/or other factors. The results provide insight into the factors that influence the vegetative propagation of desiccation-tolerant mosses and highlight the potential applicability of a rapid experimental approach for screening suitable inocula.

Data availability. Currently, data can only be accessed in the form of Excel sheets via contact with the corresponding author.

Competing interests. The authors declare that they have no conflict of interest.

Special issue statement. This article is part of the special issue " $\mathrm{Bi}$ ological soil crusts and their role in biogeochemical processes and cycling". It is a result of the BIOCRUST3 conference, Moab, USA, 26 to 30 September 2016.

Acknowledgements. The research was supported by the National Natural Science Foundation of China (grant nos. 41571268, 41271298). We also express our gratitude to the anonymous reviewers and editors for their constructive comments and suggestions.

Edited by: Bettina Weber

Reviewed by: three anonymous referees

\section{References}

Abdul-baki, A. A. and Anderson, J. D.: Relationship between decarboxylation of glutamic-acid and vigor in soybean seed, Crop Sci., 13, 227-232, https://doi.org/10.2135/cropsci1973.0011183X001300020023x, 1973.

Alpert, P.: Survival of a desiccation-tolerant moss, Grimmia laevigata, beyond its observed microdistributional limits, J. Bryol., 15, 219-227, https://doi.org/10.1179/jbr.1988.15.1.219, 1988.

Alpert, P. and Oechel, W. C.: Carbon balance limits microdistribution of Grimmia laevigata, a desiccation-tolerant plant, Ecology, 66, 660-669, https://doi.org/10.2307/1940527, 1985.

Antoninka, A., Bowker, M. A., Reed, S. C., and Doherty, K.: Production of greenhouse-grown biocrust mosses and associated cyanobacteria to rehabilitate dryland soil function, Restor. Ecol., 24, 324-335, https://doi.org/10.1111/rec.12311, 2016.

Belnap, J. and Eldridge, D.: Disturbance and recovery of biological soil crusts, in: Biological Soil Crusts: Structure, Function, and Management, edited by: Belnap, J. and Lange, O. L., Springer, Berlin, Germany, 363-383, 2003.

Belnap, J. and Lange, O. L.: Structure and functioning of biological soil crusts: a synthesis, in: Biological Soil Crusts: Structure, Function, and Management, edited by: Belnap, J. and Lange, O. L., Springer, Berlin, Germany, 471-479, 2003.

Belnap, J., Weber, B., and Büdel, B.: Biological soil crusts as an organizing principle in drylands, in: Biological Soil Crusts An Organizing Principle in Drylands, edited by: Weber, B., Büdel, B., and Belnap, J., Springer, Berlin, Germany, 3-13, 2016.

Bradford, M. M.: A rapid and sensitive method for the quantification of microgram quantities of protein utilizing the principle of protein dye binding, Anal. Biochem., 72, 248-254, https://doi.org/10.1016/0003-2697(76)90527-3, 1976.

Burch, J.: Some mosses survive cryopreservation without prior pretreatment, Bryologist, 106, 270-277, https://doi.org/10.1639/00072745(2003)106[0270:SMSCWP]2.0.CO;2, 2003.

Burch, J. and Wilkinson, T.: Cryopreservation of protonemata of Ditrichum cornubicum (Paton) comparing the effectiveness of four cryoprotectant pretreatments, Cryoletters, 23, 197-208, 2002.

Chinese Central Meteorological Station: http://www.nmc.cn/ publish/forecast/ASN/ansai.html, last access: 2 August 2017.

Cleavitt, N. L.: Stress tolerance of rare and common moss species in relation to their occupied environments and asexual dispersal potential, J. Ecol., 90, 785-795, https://doi.org/10.1046/j.13652745.2002.00713.x, 2002.

Csintalan, Z., Proctor, M. C. F., and Tuba, Z.: Chlorophyll fluorescence during drying and rehydration in the mosses Rhytidiadelphus loreus (Hedw.) Warnst., Anomodon viticulosus (Hedw.) Hook. \& Tayl., and Grimmia pulvinata (Hedw.) Sm., Ann. Bot.London, 84, 235-244, https://doi.org/10.1006/anbo.1999.0919, 1999.

Deng, J. L.: Control problems of grey systems, Syst. Control. Lett., 1, 288-294, https://doi.org/10.1016/S0167-6911(82)80025-X, 1982. 
Duckett, J. G., Burch, J., Fletcher, P. W., Matcham, H. W., Read, D. J., Russell, A. J., and Pressel, S.: In vitro cultivation of bryophytes: a review of practicalities, problems, progress and promise, J. Bryol., 26, 3-20, https://doi.org/10.1179/037366803235001742, 2004.

Gao, L. Q., Bowker, M. A., Xu, M. X., Sun, H., Tuo, D. F., and Zhao, Y. G.: Biological soil crusts decrease erodibility by modifying inherent soil properties on the Loess Plateau, China, Soil Biol. Biochem., 105, 49-58, https://doi.org/10.1016/j.soilbio.2016.11.009, 2017.

Hearnshaw, G. F. and Proctor, M. C. F.: The effect of temperature on the survival of dry bryophytes, New Phytol., 90, 221-228, https://doi.org/10.1111/j.1469-8137.1982.tb03254.x, 1982.

Hodges, D. M., DeLong, J. M., Forney, C. F., and Prange, R. K.: Improving the thiobarbituric acid-reactive-substances assay for estimating lipid peroxidation in plant tissues containing anthocyanin and other interfering compounds, Planta, 207, 604-611, https://doi.org/10.1007/s004250050524, 1999.

Hoekstra, F. A., Golovina, E. A., and Buitink, J.: Mechanisms of plant desiccation tolerance, Trends Plant Sci., 6, 431-438, https://doi.org/10.1016/S1360-1385(01)02052-0, 2001.

Hoffman, G. R.: Ecological studies of Funaria hygrometrica Hedw. in Eastern Washington and Northern Idaho, Ecol. Monogr., 36, 157-180, https://doi.org/10.2307/1942153, 1966.

Jones, P. R. and Rosentreter, R.: Gametophyte fragment growth of three common desert mosses on artificial and natural substrates, Bryologist, 109, 166-172, https://doi.org/10.1639/00072745(2006)109[166:GFGOTC]2.0.CO;2, 2006.

Keever, C.: Establishment of Grimmia laevigata on bare granite, Ecology, 38, 422-429, https://doi.org/10.2307/1929885, 1957.

Lan, S. B., Wu, L., Zhang, D. L., and Hu, C. X.: Successional stages of biological soil crusts and their microstructure variability in Shapotou region (China), Environ. Earth Sci., 65, 77-88, https://doi.org/10.1007/s12665-011-1066-0, 2012.

Lin, W. Z., Xiao, X., and Chou, K. C.: GPCR-GIA: a web-server for identifying G-protein coupled receptors and their families with grey incidence analysis, Protein Eng. Des. Sel., 22, 699705, https://doi.org/10.1093/protein/gzp057, 2009.

Mansour, K. S. and Hallet, J. N.: Effect of desiccation on DNA synthesis and the cell cycle of the moss Polytrichum formosum, New Phytol., 87, 315-324, https://doi.org/10.1111/j.14698137.1981.tb03202.x, 1981.

Mishler, B. D.: Reproductive ecology of bryophytes, in: Plant Reproductive Ecology: Patterns and Strategies, edited by: Doust, J. L. and Doust, L. L., Oxford University Press, Oxford, England, 285-306, 1988.

Morris, D. L.: Quantitative determination of carbohydrates with dreywood's anthrone reagent, Science, 107, 254-255, https://doi.org/10.1126/science.107.2775.254, 1948.

Oliver, M. J.: Influence of protoplasmic water-loss on the control of protein-synthesis in the desiccation-tolerant moss Tortula ruralis: ramifications for a repair-based mechanism of desiccation tolerance, Plant Physiol., 97, 1501-1511, https://doi.org/10.1104/pp.97.4.1501, 1991.

Oliver, M. J., Tuba, Z., and Mishler, B. D.: The evolution of vegetative desiccation tolerance in land plants, Plant Ecol., 151, 85100, https://doi.org/10.1023/A:1026550808557, 2000.
Platt, K. A., Oliver, M. J., and Thomson, W. W.: Membranes and organelles of dehydrated Selaginella and Tortula retain their normal configuration and structural integrity: freeze fracture evidence, Protoplasma, 178, 57-65, https://doi.org/10.1007/BF01404121, 1994.

Pressel, S., Ligrone, R., and Duckett, J. G.: Effects of de- and rehydration on food-conducting cells in the moss Polytrichum formosum: a cytological study, Ann. Bot.-London, 98, 67-76, https://doi.org/10.1093/aob/mcl092, 2006.

Proctor, M. C. F.: Patterns of desiccation tolerance and recovery in bryophytes, Plant Growth Regul., 35, 147-156, https://doi.org/10.1023/A:1014429720821, 2001.

Proctor, M. C. F., Oliver, M. J., Wood, A. J., Alpert, P., Stark, L. R., Cleavitt, N. L., and Mishler, B. D.: Desiccation-tolerance in bryophytes: a review, Bryologist, 110, 595-621, https://doi.org/10.1639/00072745(2007)110[595:DIBAR]2.0.CO;2, 2007.

Sabovljevic, M., Bijelovic, A., and Dragicevic, I.: In vitro culture of mosses: Aloina aloides (K. F. Schultz) Kindb., Brachythecium velutinum (Hedw.) B. S. \& G., Ceratodon purpureus (Hedw.) Brid., Eurhynchium praelongum (Hedw.) B. S. \& G., and Grimmia pulvinata (Hedw.) Sm., Turk. J. Bot., 27, 441-446, 2003.

Schonfeld, M. A., Johnson, R. C., Carver, B. F., and Mornhinweg, D. W.: Water relations in winter-wheat as drought resistance indicators, Crop Sci., 28, 526-531, https://doi.org/10.2135/cropsci1988.0011183X002800030021x, 1988.

Seppelt, R. D., Downing, A. J., Deane-Coe, K. K., Zhang, Y. M., and Zhang, J.: Bryophytes within biological soil crusts, in: Biological Soil Crusts An Organizing Principle in Drylands, edited by: Weber, B., Büdel, B., and Belnap, J., Springer, Berlin, Germany, 101-120, 2016.

Stark, L. R., Greenwood, J. L., and Brinda, J. C.: Desiccated Syntrichia ruralis shoots regenerate after 20 years in the herbarium, J. Bryol., 39, 85-93, https://doi.org/10.1080/03736687.2016.1176307, 2017.

Tian, G. Q., Bai, X. L., Xu, J., and Wang, X. D.: Experimental studies on natural regeneration and artificial cultures of moss crusts on fixed dunes in the Tengger Desert, Chinese Journal of Plant Ecology, 29, 164-169, https://doi.org/10.17521/cjpe.2005.0021, 2005 (in Chinese).

Wellburn, A. R. and Lichtenthaler, H.: Formulae and program to determine total carotenoids and chlorophylls $\mathrm{a}$ and $\mathrm{b}$ of leaf extracts in different solvents, in: Advances in Photosynthesis Research, edited by: Sybesma, C., Springer, Dordrecht, the Netherlands, 9-12, 1984.

Xiao, B., Zhao, Y. G., Wang, Q. H., and Li, C.: Development of artificial moss-dominated biological soil crusts and their effects on runoff and soil water content in a semi-arid environment, J. Arid Environ., 117, 75-83, https://doi.org/10.1016/j.jaridenv.2015.02.017, 2015.

Zhang, G. H., Liu, G. B., Wang, G. L., and Wang, Y. X.: Effects of vegetation cover and rainfall intensity on sedimentbound nutrient loss, size composition and volume fractal dimension of sediment particles, Pedosphere, 21, 676-684, https://doi.org/10.1016/S1002-0160(11)60170-7, 2011.

Zhao, Y. G., Qin, N. Q., Weber, B., and Xu, M. X.: Response of biological soil crusts to raindrop erosivity and underlying influences 
in the hilly Loess Plateau region, China, Biodivers. Conserv., 23, 1669-1686, https://doi.org/10.1007/s10531-014-0680-z, 2014.
Zhao, Y. G., Bowker, M. A., Zhang, Y. M., and Zaady, E.: Enhanced recovery of biological soil crusts after disturbance, in: Biological Soil Crusts An Organizing Principle in Drylands, edited by: Weber, B., Büdel, B., and Belnap, J., Springer, Berlin, Germany, 499-523, 2016. 